
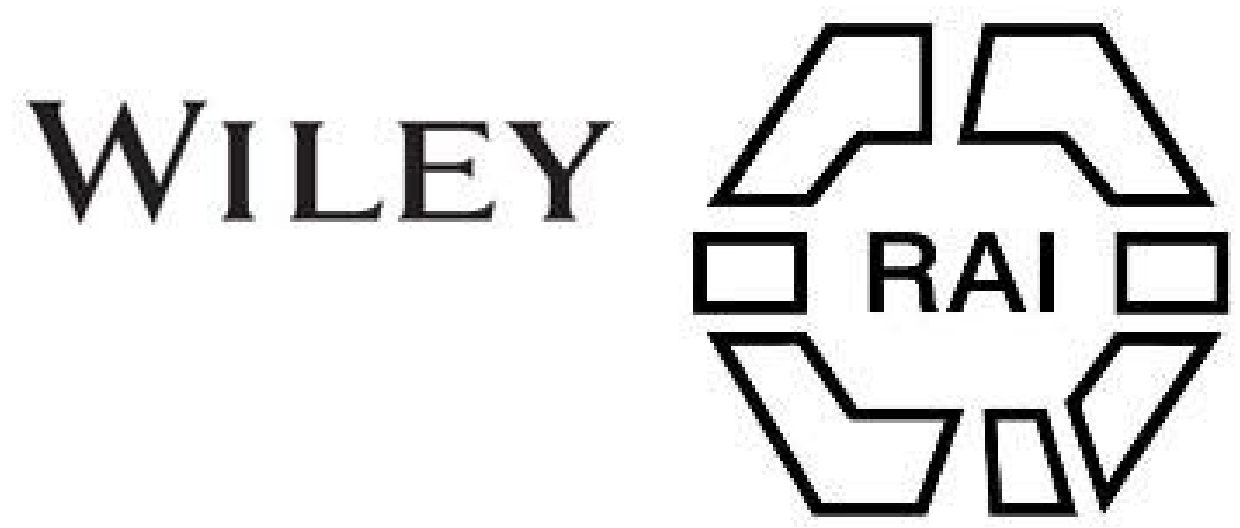

\title{
100. Stone-Headed Club from Southern Kordofan
}

\section{Author(s): C. G. Seligman}

Source: Man, Vol. 16 (Nov., 1916), pp. 170-171

Published by: Royal Anthropological Institute of Great Britain and Ireland Stable URL: http://www.jstor.org/stable/2788766

Accessed: 27-06-2016 08:42 UTC

\section{Your use of the JSTOR archive indicates your acceptance of the Terms \& Conditions of Use, available at}

http://about.jstor.org/terms

JSTOR is a not-for-profit service that helps scholars, researchers, and students discover, use, and build upon a wide range of content in a trusted digital archive. We use information technology and tools to increase productivity and facilitate new forms of scholarship. For more information about JSTOR, please contact support@jstor.org.

Wiley, Royal Anthropological Institute of Great Britain and Ireland are collaborating with JSTOR to digitize, preserve and extend access to Man 
condition. The gossips recalled that this man had often beell heard to say he would like to die with a beautiful woman.*

The danger of death aside, the use of the Jamestown Weed has risks. Two Zuñi were mentioned to me as having their skins "spotted" from using the narcotic-or from using it without a subsequent emetic, I infer Mrs. Stevenson's informant would have maintained. "Should the warm water not be druuk and the medicine thereby thoroughly ejected, the flowers of Datura would appear over the body." $\dagger$

Although the third method is Navaho, "the little people," supposedly of Zuñi origin, figure in it, for it is they again who guide the doctored hand. After the doctoring, the seer sits down and holds out his hand. When the first song is sung by his colleague the fingers of the hand begin to move in the order the medicines have been rubbed on. When the second song is sung all the fingers become "crazy" all over and numb. There is a third song to quiet the hand. In this case as in the others the seer spends the night alone. His colleague excepted, none is allowed to touch him or even see him. Should any one who did not "believe" come near him, the doctored hand would strike that unbeliever. + The room the seer stays in, too, must be emptied-lest he "hurt himself against anything." Moreover, in the Navaho method a medicine called "lion root" is rubbed on the seer, so he will not get hurt knocking about.

Nevertheless the experience is very trying. The next day the seer is upset. His head and eyes are heavy. He feels nervously on edge, "as you would in a thunder-storm," he said. So trying, indeed, is the performance, that, lucrative as it is - a seer might be given as much as $\$ 10$ worth of blankets-my friend has retired from practice. He is too old, he says, it hurts too much. Only a few months ago he declined a case of a lost horse.

ELSIE CLEWS PARSONS.

\section{Kordofan : Ethnography.}

Seligman.

\section{Stone-Headed Club From Southern Kordofan. By Professor Seligman, M.D.}

When travelling in Southern Kordofan in 1910 I saw a certain, not very large, number of clubs with spherical or sub-spherical heads. The finest example, illustrated in the accompanying figure, and now in the British Museum, was obtained from the Lafofa of Jebel Eliri. The head, which has a diameter of about $6.5 \mathrm{~cm}$, is of smoothly ground hard igneous rock, consisting of a black matrix embedding many angular or sub-angular whitish masses. As shown in the figure, this is hafted on to a stout and very strong kind of cane about $80 \mathrm{~cm}$. in length; one extremity of the cane has been tapered to receive the stone, the fastening being made secure by a rough iron ferrule hammered over the end.

I could not ascertain the exact provenance of these clubs, which were far from common, but it seems certain that they were not made on any of the hills between the Nile and Jebel Talodi, nor did I see any during a journey in Northern Kordofan,

* According to Cushing tenatseli (te-net-sa-li) is a love charm, making women follow jts possessor. -Proctor, F. D., The Song of the Ancient People, p. 59. New York, 1893.

$\dagger$ "The Ethnobotany of the Zuñi Indians," p. 90.

$\ddagger$ One case was told me where, because the client did not believe, "the little people" had not appeared to the seer and his vision was imperfect. He could only tell his client she would find the lost property-some money--the following day before noon. The seer and his singer departed, leaving the woman much put out for having had to pay for such inadequate information. So angry did she remain, in fact, that the next morning she began a search on her own account for her lost money. Just as the seer and the singer were returning to give back to her their pay, they having heard of her dissatisfaction, at that very moment she found her money tucked away in an old box, and it was not yet noon. 
in 1912, from Bara to beyond Jebel Kaja, in the neighbourhood of the Darfur border, although MacMichael has figured a number of pierced stones, some of which are sub-spherical, from Jebel Haraza and Jebel Um Durrag, in Northern Kordofan.* Probably the club-heads are, or were, made somewhere in Central Kordofan; the specimens I examined were not all of one kind of rock, nor was the hafting in every case of the same quality.

With regard to the purpose of these clubs, it was said that they would be used in fighting and hunting the larger carnivora, when an attempt would be made to strike a powerful two-handed blow on the neck immediately behind the base of the skull.

Their occurrence in North-Central Africa is of considerable interest. They are unknown among the Negro tribes; the form of the stone has nothing in common with the perforated dises from Meroitic sites, which I have described elsewhere, and it is by no means certain that they are in any way related to those figured by MacMichael. The question arises whether, in spite of their smaller size, they may not have, some affinity with the Bushman !kwe, or pierced stones used for weighting digging sticks. A pierced stone, considered by Peringuey to be a lkwe, has been found on the Tanganyika plateau, while the same author has published a bushman painting in which a pierced stone is shown hafted as a club. $\dagger$

C. G. SELIGMAN.

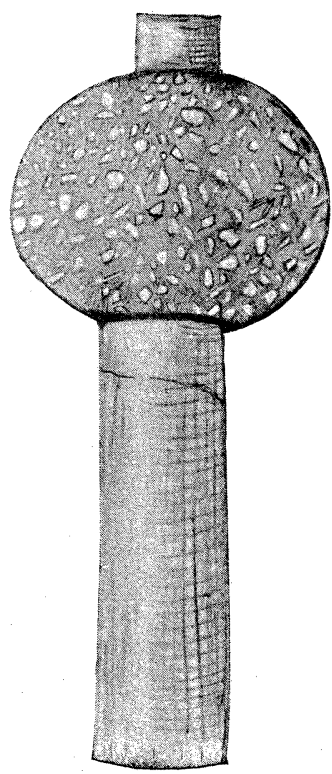

STONE-HEADED CLUB FROM KORDOFAN. $\times \frac{1}{2}$.

\section{REVIEWS.}

France: Archæology.

Baudouin.

La Sépulture Neolithique de Belleville a Vendrest (Seine-et-Marne), Fouille et Restauration. Étude scientifique. Rapport Général par le Dr. Marcel Baudouin, avec la collaboration de MM. L. Giraux, A. Guébhard, Edmond Hue, Henri Martin, Ph. Reynier, et E. Taté. Paris. Société Prehistorique Française. 1911. 40 Figs. in text, 16 Plates. Pp. 264.

L'Ossuaire de la Ciste des Cous. A Bazoges-en-Pareds (Vendée) par Dr. Marcel Baudouin et Lucien Rousseau. Extrait des Mémoires de la Société Prehistorique Française (1914-15). Paris. Bureau de la S.P.F. 1915. 10 Plates, 44 Figs. Pp. 91.

In the summer of $1908 \mathrm{M}$. $\mathrm{Ph}$. Reynier, of Lizy-sur-Oureq-a small town some 30 miles to the north-east of Paris, and situated in the Department of Seine-et-Marne -informed the council of the Prehistoric Society of France that a Neolithic sepulchre of a peculiar kind had been discovered in the neighbouring parish of Vendrest. The site of the discovery was on the southern flank of the small wooded hill of Belleville, the sepulchre being situated about 130 feet above the level of the adjoining valley. Great sandstone blocks occur on the hill, which are hewn at the present day for paving purposes. It was while engaged on one of these great blocks-one which proved to be an essential part of the roof of a tomb-that the workmen discovered the Neolithic sepulchre of Belleville. The Council of the Society at once took steps (1) to purchase the site for the nation; (2) to carry out a complete and systematic

* The Tribes of Northern and Central Kordofan, p. 88 . These stones are not used as clubheads, and probably - as suggested by MacMichael-they are to be regarded as indicating northern (Meroitic) influence.

$\dagger$ Annals of the South African Museum, VIII (1911), pp. 112, 113.

$$
\text { [ } 171 \text { ] }
$$

